\title{
Community-Based Policing in Nicaragua: Do the Claims of Communitarian, Proactive and Preventative Hold True?
}

\author{
John-Andrew McNeish ${ }^{1, \star}$, Skarlleth Martinez Prado ${ }^{2}$ and Hugo Frühling Ehrlich ${ }^{3}$ \\ ${ }^{1}$ Norwegian University of Life Sciences (NMBU), Ås, Norway \\ ${ }^{2}$ Nicaraguan Institute of Strategic Study and Public Policy (IEEPP), Managua, Nicaragua \\ ${ }^{3}$ Institute of Public Policy, University of Chile, Santiago, Chile \\ *Corresponding author: E-Mail: john.mcneish@nmbu.no \\ Submitted: 10 January 2018 | In revised form: 15 June 2018 | Accepted: 26 June 2018 | \\ Published: 30 May 2018
}

\begin{abstract}
Until the wave of political violence in 2018, the Nicaraguan model for community-based policing (COP) was viewed by many as the means by which the country had avoided the crime and insecurity reported elsewhere in Central America. Paralleling these positive claims, the Nicaraguan National Police have emphasized particular characteristics of the COP model as the basis of this success. The Nicaraguan COP model is founded on three ethical pillars i.e. that it is communitarian, proactive and preventative. In this article, we detail the development of the Nicaraguan community-policing model and evaluate its historical and persisting significance as the guarantor of law and order through a critical evaluation of these claims and characteristics. The article demonstrates the abiding significance of the Nicaraguan COP model, and the distinctive nature of its operation. In contrast to prevailing regional trends there is much to learn from policing that emphasizes dialogue with the community over a reliance on technological or strong-arm solutions. However, the article also observes severe challenges regarding its current capacities and its erosion as a result of the pressures of presidential authoritarianism, political corruption and securitization. This erosion of the COP model has negatively affected the conditions of human security in Nicaragua and is a significant factor explaining the character of recent violence.
\end{abstract}

Keywords: civil unrest; community-based policing; crime; Nicaragua; security

\section{Introduction}

Multiple publications have claimed in recent years that Nicaragua had escaped the wave of crime and insecurity suffered by its neighbors [1-3]. The Nicaraguan model for community-based policing (COP) was heralded in particular as a success story in a series of reports written by international organizations [4,5]. A series of donor institutions also praised the Nicaraguan community-based policing model. They suggest that the COP model is a key reason why the country has been able to avoid the serious conditions of organized crime, violence and homicide registered in the Northern Triangle countries (Guatemala, El Salvador and Honduras) $[6,7]$. The recent wave of political unrest and multiple violent clashes between the national police and protesters that have left over ca. 400 people dead [8] suggests that these claims were overstated. These events have taken many observers by surprise. However, as we observe below recognition of a series of political reforms and changes to police practice, and the Nicaraguan community based model 
in particular, assist explanation of both the country's earlier success in combatting violent crime and the current national crisis in political and public order.

Drawing on recent qualitative research [9], in this article we critically consider what is distinctive about the Nicaraguan COP model. In order to consider its strengths and weaknesses the article evaluates the Nicaraguan COP model's own claims to distinction i.e. that its success is based on homegrown foundations of policing as communitarian, proactive and preventative. The article initially explores the regional setting for community based policing. The article proceeds from this to a direct exploration of the distinctive origins and nature of Nicaragua's COP model. The Nicaraguan COP model is as much the product of the Sandinista Revolution as later attempts in sync with regional trends towards professionalization and institutional reform. Attention is furthermore given to each of the claims regarding the model's foundations and consideration made whether current dynamics sustain or problematize their function. In progressing through an analysis of each of the model's foundational claims it should be evident that the article aims to form a balanced critique of the Nicaraguan COP model. As such, recognition is made of its achievements, but also evidences made of internal institutional challenges and new external threats. In conclusion, we furthermore highlight how the recent reform of security policy and changing police practice have had severe consequences for the conditions of human security in the country. The recent turn from COP to a reactive form of policing has heightened tensions between local communities and the police and contributed to the violent episodes that have taken place in the country in recent months.

\section{A Safe Haven in a Violent Region}

Efforts to reform the police forces in Latin America multiplied throughout the region in the 1990s [12], encouraged by the return to democratic rule of law across the region in the same period. The wave of reform matches the trend for the introduction of COP programs in other post-conflict contexts elsewhere in the world [13]. The signing of peace accords between the governments and armed opposition in El Salvador and Guatemala respectively in 1991 and 1996 was particularly significant for police reform. In both cases, the peace accords stipulated the creation of new civilian police forces to replace the former police forces that had operated under the auspices of the military. In the years that followed, initiatives of police reform extended throughout the rest of the region. These processes of reform were strongly influenced by two main trends in international policing.

On the one hand a COP model was adopted based on practices developed in North America and Europe during the 1980s. This model was strongly supported by multilateral institutions such as the Inter-American Development Bank, which saw the change as an appropriate path towards more democratic policing [14]. COP aimed to deal with the causes of crime rather than simply responding to it- by empowering citizens, building police community part- nerships, improving social services and generating better crime statistics [15]. Street patrols, policy councils and youth services are some of the many programs adopted by Latin American COP models [15]. In Latin America developments focused on COP were often paralleled by another trend towards professionalization and the formation of specialized units-sometimes with renewed linkages to the military. In response to public and media pressure and reactionary political leadership there has also been a tendency to resort to militarized responses. These initiatives rely on reactionary and repressive policies that seek immediate short-term results [16].

Nicaragua does not depart from the general pattern in the region in which states have placed an emphasis on the professionalization of the police and engaged the armed forces in public security tasks. Its adoption of a COP model does, however, predate others in the region. Indeed, instead of an emphasis on force, technology and spending [17], Nicaragua contrasts with other Latin American countries due to its long-term development of a model centered on state-community relations. According to the National Police its ethical aims of prevention and foundation in the community not only permeates the actions of individual police officers, but also guides the structure, organization, deployment and entire philosophy of the national police force [18]. The Nicaraguan Police claim that it is the combination of communitarian, preventive and proactive policing that is at the foundation of its success in retaining order. Put simply it is in this way the police can work "from the community, for the community and with the community" [19].

Commonly the Nicaraguan police and governmentparalleled by elements of the donor community including the Swedish Department for International Development (SIDA), Norwegian Department of International Development (Norad) and the European Union-evidenced the success of the Nicaraguan COP model by highlighting the relatively low levels of homicide in the country. Nicaragua registered its lowest homicide rate during the last 15 years in 2014 with 8 murders per 100,000 residents, according to statistics from a police report released in April 2015 [20]. Official statistics from 2016 suggest a further drop to a total of 453 homicides i.e. 7 per 100,000 [21]. These tendencies are contrasted with the rising figures registered in the Northern Triangle (EI Salvador, Guatemala and Honduras) [22]. According to police data, these countries collectively saw 17,422 murders in $2015,11 \%$ more than in 2014 [23].

\section{A Communitarian Police Force}

Existing studies recognize that the shape and practice of the Nicaraguan COP model is not only the result of moves towards professionalism sparked by the broader trend for COP in the 1990s, but also the result of several generations of change and reform [24-26]. Secondary sources reviewed for this article also commonly connect the "communitarian" origins of the police force with the country's experience of the Sandinista Revolution (1978-1990) [27]. Whilst one of 
three Central American countries to pass through a period of civil war, Nicaragua is distinct from the others given that the Sandinistas not only managed to politically leverage a peace deal, but to militarily succeed in taking power through revolution. The success of the Sandinista Revolution in taking power and its introduction of a political system built on ideas of socialism are significant in providing an explanation for the basis for policing and security established in the post-conflict period. This also contrasts with the timing and origins of COP models adopted in the Northern Triangle. Although the ideological and religious basis of the government has been periodically challenged-both politically and through armed insurrection (Contras war 1981-1990)- the inheritance of ideas resulting from the Sandinista revolution remain evident in current political practice and dialogue.

Cuadra [28] highlights that before the triumph of the Sandinista Revolution, Nicaragua did not have an institution that assumed the functions of an independent police force. In the period of the Somoza government, the National Guard carried out these activities as part of its function to secure the internal order of the country; but without specialisation, political independence and the autonomy exercised by the military. It also lacked structure, organisation and clearly defined tasks in this regard. The National Guard is the immediate successor of the "Constabulary" that was created by the United States during their occupation of the country (1912-1933). The Constabulary was founded in 1927 in the context of US intervention, as an armed body that fused together all policing and military functions. This apparatus continued for four years after the retraction of the US Marines (1937) and remained an institution loyal to the service of the governing Somoza regime.

The defeat of the Anastasio Somoza dictatorship also marked the end of the National Guard, and their substitution by the Sandinista Popular Army and the Sandinista Police. The Sandinista Police were founded on the 5th of September 1979. With their establishment, the new government aimed to end the history of open repression carried out by the earlier National Guard. The first police officers of the new national force were mainly young people who had participated actively in the insurrection against the Somoza regime. Although very different from the National Guard, the new police force also submitted themselves to the governing class and their leadership. From 1979 onwards, the Sandinista government decided to separate the functions of defence and security from that of public order. This resulted in the creation of the Ministry of Defence and the Sandinista Popular Army; and the Ministry of the Interior and the Sandinista Police. The New Sandinista Police force initially counted on the advice and training of Panama, but its equipment and professional training drew mostly on socialist policy (and particularly the example of Cuba). From 1979 to 1989 , the police force was formally tasked "to guarantee the status quo and property with revolutionary sentiment, confront crime and assist the task of securing the state" [28].

Speaking about this period of time a former police officer recounted the following in an interview [29]:

"What they created was a system to defend the revolution. Everyone was to defend the Revolution and local defence committees were initially structured to provide labour towards the construction and maintenance of basic services, water, light, the street etc. Following this they started with the distribution of basic food stuffs and efforts to defend the revolution through neighbourhood supervision".

Throughout the 1980s the police formed part of the broad defence of the revolution in which they were assigned the task of preventing crime and counter-revolutionary activities. This was implemented with a strong emphasis on participation from the public. In response to the drastic economic measures adopted by the Nicaraguan government at the end of the 1980s and with the aim of counteracting the legacy of war, the Sandinista Police started a process of experimentation in which a significant reduction was made of its technical, human and material capacities. Significant cuts were made to the budgets of all parts of the state apparatus. At the same time there was an increase in the level of crime. This in turn influenced the capacity and attitude of the police force to exercise the functions with which it had been entrusted.

With limited resources and personnel the Nicaraguan National Police (PNN) was forced to decentralise its responses to crime and manifestations of insecurity. It did this by establishing broad and permanent channels of communication with the community, both through the formation of community-assemblies and maintaining direct links with local residents. In the 1980s, the Nicaraguan police introduced two important elements of their current COP model i.e. committees for the defence of the revolution (Comites por la defenda de la revolución-later to become Committees for Citizen Power-CPCs) and jefes de sector (heads of sector). Whereas the committees would become a key point of articulation between the police and the families, the heads of sector would become specialists in public neighbourhood security.

In 1989, the police force's position in relation to the Ministry of the Interior was ratified by Law No.65 "Law of the Functions of the Sandinista Police" in which it was defined as an "organ of the Ministry of the Interior". In contrast to its earlier formal remit to defend the state and popular revolution, the police were now tasked with the protection of the life and physical integrity of the country's civilian inhabitants. They therefore assumed responsibility for the prevention of crime and preservation of public order. The police were also expected to embody the particular and social values of the country and to provide assistance to other state institutions to comply with the law and to carry out their legal obligations.

In 1990s, following an intense process of transformation and institutional modernization, the relationship between the police and community was redefined yet again. It is important to note the coincidence of these changes with 
the election of the liberal Chamorro government (19901997). The Chamorro government rejected the socialist premise of the earlier government and of its efforts to organize the masses. During this process the National Police implemented the concept of public security as its principal doctrine and established the conception and philosophy of public service and prevention. As such the new model was, as one interviewee has commented, "aimed at 1. depoliticizing the national police and 2. removing party-based alliances". The intentions of professionalization and modernisation of the police was further accompanied by an effort to strengthen human resources in organisational aspects, as well as improvements in candidate selection and training. In this period they also formally introduced a focus on gender equity as a crosscutting theme within the organization and actions of the National Police [30]. In addition, the Police based their legal foundation on a newly reformed political constitution [31]: "The National Police is a armed body of civil nature. It has as its mission the guarantee of internal order, the security of the citizenry, the prevention and prosecution of crime and other activities specified by law". The police doctrine is founded clearly in the service of the community and signals that the work of the police only makes sense through its extensive relationship with it. The Law of the National Police defines clearly how to "secure exchanges and collaboration with different civil society organisations with an aim to the joint implementation of solutions to the problems faced by communities" [32]. The Police further strengthened their relations with civil society and established further points of coordination on issues of crime prevention. Particular attention was given to the intrafamily and sexual violence. This process culminated in the creation of the Mother and Child Stations. These stations were born out of a joint initiative between the civil society and the National Police, as spaces that provide integrated attention to the victims and survivors of intra-family and sexual violence.

In the process of modernization, the National Police proposed the institutionalisation of the issue of gender in the institutions policies and practices. This is described as a search for a better symmetry in relations between women and men within the institution, and the articulation of an increased role for women in police work [33]. The process of professionalization of the national police in the 1990s also included the introduction of a programme aimed at the prevention of adolescent crime. In 1995 the national police introduced a strategy targeting adolescent crime and related gang violence. In contrast to other Central American countries, adolescent crime was recognised not only an issue of public order, but as a social problem. The programme aimed to address the issue of adolescent crime not by force, but through a system of youth education and promotion. The police established a number of Centres of Youth Formation and Development (Centros de Formación y Desarrollo Juvenil) where adolescents identified by their families and the police were encouraged to enter vocational training programmes and a system of follow up and super- vision by designated police officers [34].

These developments lead up to the formal introduction of the current Preventative Community Policing model. On the 20th November 2001, following Decree No 0426-2001, the Director General of the National Police, First Commander Edwin Cordero Ardila established the Integrated PoliceCommunity Policy. This policy is conceived of as an instrument permitting the promotion of a change of attitude amongst members of the Police, and the facilitation of direct relations between the police and the community in order to achieve its institutional mission with increased efficiency and efficacy. Guido [35] indicates that the stated aim of this policy is to contribute to the improvements of the quality of life of the population, and particularly with regards to citizens' security, guaranteeing the relationship between the institution of the police with the communities, putting in place preventative work and activities aimed at optimizing the quality of police services. The main features of the policy are based on the establishment of social relations connecting with the interests of different social groups in the community: the prevention of crime at the level of the community; a focus on gender and prevention amongst children and youths; respecting human rights and constitutional guarantees for individuals under police custody and their families [35].

In 2003 a further important ingredient of the current COP model was added. Family assemblies (Gabinetes de la Familia, la Comunidad y la Vida) would replace the earlier functions of the CPCs. According to official statistics there are now more than 100,000 people within the network of "social prevention" constituted by the family assemblies and other related community assemblies [36].

The central goal of the current model is the operationalization, mainstreaming and integration of COP as a joint action in all areas of specialisation within the national police. It has its formal expression in the operative plans implemented at the level of sector, municipality, delegation and police district, and national level. The relationship between police and community is established principally through visits to homes, community and religious leaders, organizations for social education and protection of children and women, amongst others. It encourages the open participation of men and women and their proactive contribution in proposals for prevention and solution of different problems that affect their rights and freedoms.

\subsection{Still True to the Community?}

Daniel Ortega, one of the key leaders of the insurrection against Somoza and the first post-revolution president in 1984, returned to the Presidency in 2007. In compliance with President Ortega's orders, in July 2014 Nicaragua's National Assembly approved a new law largely returning control over the country's police force to the President. This move has sparked accusations by political opponents that the new law removes the institution's independence and increases the risk of police corruption through political ties. 
The "Law of Organization, Functions, Career, and Special Regimen of Security of the National Police" makes the president "supreme commander" of the institution, alongside other clauses that restructure and provide institutional support for the police force. The legislation also replaces the National Police Law dating from 1996, under which the police fell under the control of Nicaragua's Interior Ministry. The new laws eliminated the supervision and intermediation of the Interior Ministry (Ministerio de Governación)[37], leaving the direction of the institution to be decided by the relationship between the leadership of the police and the president. This decision contradicted the previously agreed Framework for Democratic Security given that it removes any functional autonomy of the national police and any limitation in terms of their role in terms of protecting public security. It also contradicted the General Treaty on Democratic Security in Central America, in which there is clear emphasis on the need for an autonomous supervisory body to oversee the operation of the Police. As analysts recognized [38], without the existence of such an authority or other suitable mechanisms of control and oversight, there is always the risk of an abuse of power and failure to protect the personal security of individuals.

In 2015 the Nicaraguan government also approved the establishment of a new Sovereign Security Act. The Act's stated objective is to "preserve, promote, and maintain sovereign security" against threats that include transnational organized crime, international terrorism, foreign interference, criminality, rebellion, illicit acts against aviation and maritime navigation, attacks against cyber security and infrastructure, or "any illegal act that threatens against the existence of the Nicaraguan state and its institutions." Whilst largely in support of the claims to defend sovereignty and territorial integrity, civil society organizations in the country fear that the new act is being misused by the presidency to outlaw the presence of certain non-governmental organizations in the country as well as restrict participation in the national democratic political system. The police's use of force to stop and break up protests against the government or focused on issues such as the proposed canal are now characterized by government communications as necessary in the interest of pubic security and national strategic interest. Critics, however, suggest that something else is occurring [39].

Roberto Cajina (a well known regional security analyst) in a recent blog-post suggests that the hard handed actions of the police forces in Managua represents "the profound systematic crisis in which the Police finds itself, in which the police are now denaturalized and converted into a body at the service of a dynastic project and the continuance of Daniel Ortega" [40]. Further signs that democratic conditions are worsening include the way in which the government has used to the judicial system to ban the majority of the political opposition in the run up to elections in November 2016 [41]. The fact that President Ortega positioned his wife as candidate for the vice-presidency has also given further fuel to arguments of the existence of nepotism and a worsening relationship between the state and community.

These changes indicate a general drift away from earlier democratic and revolutionary structures and ideas. There are also specific indications that resulting changes to everyday policing has had a direct impact on the possibility to sustain strong community linkages and public respect. Throughout the country there are falling rates of confidence in the police and public security. In interviews carried out in early 2017 analysts and ex-officials detailed at length a series of factors that demonstrated this falling confidence. Reports produced by research institutions highlight that whilst homicide rates remain comparatively low; public opinions regarding security and crime have changed. Critics also suggest the government's use of homicide figures alone is misleading given that they do little as indicators of the status and quality of policing and public security [42].

According to a survey conducted in 2013 on the topic of public security by the Institute for Strategic Study (IEEPP), the majority of people in the survey reported feeling safe in their neighbourhoods (only 1 in 10 did not) a series of significant concerns were raised $[43,44]$. The survey included 1,600 interviews with a broad spectrum of the public and was carried out across 56 municipalities in the country, including the Atlantic Coast. Robberies remained a concern (4 of 10), but there was a visible shift to the sectors this affects. There had been an increase of robberies taking place not only of homes but of businesses. The increasing level of drug use in Nicaraguan society has also been a significant concern (1 in 10). In 2013 there was an increasing level of traffic accidents and the lack of police presence was a problem. Also of note according to the survey was that of 100 hundred people experiencing a crime 49 will not have made an official report of its occurrence to the police. Many people responded that they did not report a crime because it would entail the loss of time and money, and that there is often poor response and follow up by the police.

In IEEPP's 8th (2016) survey of public perceptions of security they report that $48.9 \%$ of the population that had been victims of crime in the final months of that year had not reported it the police [38]. The explanations for this ranged between the low levels of seriousness of the crime, because it was a waste of money and time, the lack of attention and response of the police or fear of reprisals from criminals. Although the report highlights that confidence in the police remains comparatively high, negative perceptions were growing. Respondents to the survey with a negative perception had grown to what their annual report describes as an all time high of $16.9 \%$. They also report that there is an increasing tendency to refer to the operation of the police force itself, and in particular problematic elements of its operation to secure local neighbourhoods and transit.

In a number of news reports from 2016 analysts from the same institution claimed that there was also increasing evidence of people taking the law into their own hands [45]. In connection with this they point to the rising number of individuals who have purchased firearms for home protection. In our interviews with the national police the accuracy 
of claims regarding the increase in the private purchase of arms is contested [46].

According to a number of our interviewees the transference of responsibility for programs aimed at youth, community sports, mothers and children and at combatting domestic violence to other government institutions has changed the quality of police-community relations. Whilst from the outside these programs appeared to be beyond the bounds of the public security mandate of the police, they are acknowledged by national analysts as having enabled both a close and effective relationship between the community and the police. The recent movement of responsibility for these programs (the Centros de Juventud remain under police jurisdiction) whilst given explanation in terms of increasing institutional efficiency, is interpreted at least by some commentators as a politically motivated strategy by the Presidency to co-opt the popular support surrounding these programs. Interview respondents, including ex-police chiefs, commented in early 2017 that this change was shortsighted given its effect on COP and the effective flow of information regarding local conditions of insecurity.

\section{Proactive Responses to Insecurity}

Family assemblies and heads of sector are two of the distinctive feature of the Nicaraguan community-policing model. Indeed, it is these two features are largely recognized as enabling the Nicaraguan police's claims to proactivity with and within the community. These "social technologies" also stand out in contrast with the more costly technologically driven and patrolling strategies used by other COP efforts in Central America.

The family assemblies were established to renew and to continue the work of the earlier CPCs as participatorymechanisms for the expression of popular concerns and interests. According to Article 290 of the 2013 Constitution the gabinetes de familia (Family assemblies) are organized by:

"... individual adult men and women, teenagers and pensioner that live in a community, to reflect on and work together to promote values and family unity, self-confidence and mutual esteem, responsibilities, rights and obligations, communication, co-existence, understanding and a spirit of community so that they form coherence between how they think and act".

By setting a schedule of regular meetings and workshops, the assemblies are meant to create spaces where a series of issues facing the community can be openly discussed and resolved i.e. health; education; sanitation; the promotion of local culture and religious festivals; citizens security; the promotion of the rights of women and children; the protection of families and their rights; the prevention and attention of violence against women, inter-family and youth violence; training and organization to confront natural disasters, promotion of community identity, and humani- tarian assistance to cases of abandonment, disability and dementia. The family assemblies are widely seen by the people we interviewed as having a significant role in the solution and mediation of intra-familial violence.

With regards to issues of crime and security in the community, the gabinetes de familia act as a point of direct articulation between community and the police. This is further facilitated through the direct participation in assembly meetings and seminars of the police's own heads of sector (jefe de sector). These are community police officers that, in contrast to other Central American policing models, live in rather than just patrol local neighbourhoods and communities. Indeed, the jefes de sectors are often recruited from within the same community that they serve as a police officer. They cultivate close community ties through door-to-door visits with their neighbours and their participation in meetings with local residents. They also represent a point of articulation with the national police and the state. As such they ensure that information gathered from the community is passed directly up through the chain of command with the national force. As one sector head stated in a recent article "Our mission is to guarantee citizen's security in all aspects, so that the people are at peace... and it is the jefe de sector that has the role of approaching both the police and the community, so that the community feels secure and knows to who they should turn in trying to resolve their problems" [47].

In addition to these two key features of the Nicaraguan policing model, proactivity in terms of the provision of quick responses to community concerns and interests has been aided by the operation of the Centres of Youth Formation and Development (Centros de Formación y Desarrollo Juvenil) in Managua and Bluefields-both cities with significant problems with juvenile crime (Rodgers 2013). The centres were set up by the national police in 2011 with the expressed intention of creating spaces to rescue young people who have become addicted to drugs or who had become involved in criminal activities and gangs. A series of international donors have supported these centres, including the Spanish government and the European Union. The Centres provide these young people with a place to stay, to take part in social and sporting activities, to learn about citizenship and to receive vocational training. During the opening ceremony for the Centre in Managua the First Commissioner of the National Police Aminta Granera commented [48] on the role that the centres were to play:

"The police are part of the community, not something distant from it. . . it is important that it moves in unison with the feelings and life of the community. It is from there that it can privilege prevention, intimacy, and the protection of people in the community. The Youth Centres are the deepest and visible expression of this spirit of the Police, attempting to come close to young people in delicate situations, in situations of risk, not to punish them but to open a space for their regeneration and formation. It is not about accompanying them to the prison, but accompanying them in their education". 


\subsection{Proactive or Political?}

Whilst these three elements of the Nicaraguan COP model are recognized as essential elements in the proactive response to crime, critics voice concerns about the way in which they also play a political role by embedding the Ortega Sandinista administration within the community. When the family assemblies (Gabinetes de familia) were introduced in 2013 several media channels and analysts highlighted that this was an attempt to impose a particular model of citizen control in the country. As mentioned above the family assemblies were meant to replace and update the role of the previous Citizens Power Councils. However, observers also noted that this really meant the formation of a closer relationship with the particular interests of Ortega, in contrast to a broader conception of deliberative democracy [49]. Indeed, it was observed that the assemblies were part of a policy package initiated by the first lady, Ortega's wife Rosario Murillo, termed Vivir bien, vivir bonito, vivir sano (Live well, live beautifully, live healthily). At the time of their introduction a deputy of the Movimiento Renovador Sandinista (MRS) was reported as saying that the assemblies:

"Clearly politicize public policy. Now to have access to public benefits you need to have connections to the governing party, now called family assemblies. They are going to create more discrimination and exclusion compared to what there is at present" [50].

According to an opinion piece written for the La Prensa newspaper, although given legal validity by the Family Code (Código de la Familia) the assemblies "violate the principles of liberty, affecting rights and distorting the true conceptualization of citizens participation" [51]. Although the national constitution emphasizes the freedom of religion and expression, according to paragraph 32 of the Code, the assemblies must aspire to Christian values, Socialist ideals and practices of solidarity. In listing the positive values of the assemblies another report emphasizes the manner in which the assemblies are formed to promote "Christian values, family values and unity, self-confidence and esteem for others, responsibility, rights and duties, communication and harmony" [52]. Article 49 of the national constitution establishes the right of Nicaraguan citizens to organize on the basis of their willing participation and election of citizens, something that is in clear contrast to the specified form of behavior and principles written into the Family Code.

Although not stated in quite so strong terms, there was acknowledgement in our recent interviews that the Jefes de Sector and Centros de Juventud might also operate as mechanisms to cultivate support for the Ortega administration. Some interview respondent voiced the opinion that whilst the Youth Centers played an important role in reducing youth crime they did not agree with the "political re-education" provided there.

With regards to the jefes de sector party alliances were more commonly connected with problems of institutional stagnation. Indeed, a number of interview respondents commented on the manner in which party alliances and control negatively affected the growth and professional development of the national police as a whole. Because the administration controlled appointments and promotions at the top and bottom of the police's institutional structure a number of problematic tendencies could be observed. Party alliances meant that there was a high degree of circulation of the same people for top positions, and control over the acceptance of candidates into the role of jefes de sector. These alliances also meant that over time there was an over promotion of people at the top of the institution, and very little at the bottom (once in their role as jefes de sector police officers have little opportunity to move elsewhere in the institution) resulting in an overly top-heavy and aging leadership structure. Indeed, having reached the top there was commonly nowhere else for well-qualified people to go, as there was little emphasis placed on further education and specialization. As one ex-director of the national police commented in an interview with us "Nicaragua is now known in the region to have more leaders than followers, at the same time as wages at the upper level of the national police remain low compared to other countries in the region". The ex-director also emphasized what he saw as a clear need for a generational shift in command in order to respond to the changing values and mindset of the population. Following the recent national security reforms, the regulations for appointments (Article 47, Law 872) were changed allowing Aminta Granera to remain indefinitely in her position as First Commissioner of the National Police [53]. Granera chose to leave her position as Police commisioner following the unrest in 2018.

As much as political alliances and relationships are responsible for problematic actions they are also held responsible for certain forms of inaction. Numerous news reports within and without Nicaragua highlight the active role that the police have had in quelling political rallies and demonstrations [54,55]. However, news reports covering the occurrence of land invasions and conflicts surrounding mining in the Autonomous Regions of Nicaragua have tended to highlight the absence of action by the national police [56,57].

The Autonomous Regions of Nicaragua - the North Atlantic Autonomous Region (RAAN) and the South Atlantic Autonomous Region (RAAS) - were created in 1987 and elected their first regional governments in 1990. The creation of the Autonomous regions, where semi-autonomous status is given to various forms of local community leadership forms, reflects the region's contrasting history of indigenous ethnicity [58], political alliances (the focus of the Contras struggle in the 80s) and largely separate and poorer economic circumstances to the rest of the country. The communities that make up the population [59] of the Autonomous Atlantic Regions are located in territories-often with high ecologic and environmental vulnerability-with a strong sense of ownership of communal lands in coastal 
and forest areas. The creation of these regions created a new layer of government that would, at least in theory, grant greater "local" control to indigenous communities and traditional peoples over these regions and their natural resources. The constitution recognizes the right of Caribbean Coast communities to preserve and develop their cultural identity, forms of organization and property, as well as the use and enjoyment of "the waters and forests of their communal lands" (Art. 89) Larsen \& Lewis Mendoza 201 [60]. The autonomy statute established the regional councils as the "maximum authority of the regional autonomous government". The councils are entities created for deliberation, resolution, regional public policy formation and negotiation. The national police and the military retain however the role of the enforcement of law and order in the Autonomous regions in communication with these local authorities.

While then there is an agreement on the provision of security to local communities by officials of the Nicaraguan state, the Autonomous Atlantic Regions have remained a zone of periodic violence, quite in contrast to the rest of the nation. Twenty one indigenous men have been killed since 2014, women raped and dozens more wounded or kidnapped in connection with a series of confrontations over land and resources. Local non-governmental organizations blame the violence on the increasing waves of settlers that have headed to the Atlantic coast because of severe droughts in the West of the country that have decimated farming and cattle ranching.

The government's support for the construction of a new trans-oceanic canal is also widely recognized as a cause of recent unrest in the region [61]. A study carried out at the beginning of 2015 by the Nicaraguan Network for Democracy signals that the construction of the canal would result in the displacement of more than a 100,000 inhabitants across 13 different municipalities. The report also describes the experiences of local inhabitants in the Atlantic region affected by the state's preparations for the project. These include experiences of fear, intimidation, physical threats and an invasion of their personal privacy by police and security forces, and in particular of those involved in local protests.

The development of a series of gold mines in the Northern Autonomous District has also acted as a magnet for people seeking employment and wealth. The law-based on a 2001 landmark case [62]—requires outsiders, including the national government, to request permission from local authorities before they can buy or settle land. The violence has indicated that the law is not only being ignored, but that land has been taken by force. Importantly, it is also claimed that because of political linkages that exist between the government administration and the colonos (colonizers) the police and military have been instructed to not intervene in the conflicts. Some say that the National Sandinista Liberation Front is hoping to repopulate a region that was largely anti-Sandinista during the civil war in the 1980 s, and gain access to valuable natural resources such as lumber and gold [63]. Indigenous leaders claim that local functionaries of the government with connections to the timber companies have been assisting the colonizers to access automatic weapons [64]. Sadly as the violence connected to land invasion in the Atlantic north continues an increasing number of people are reported by the local media to have been displaced from their ancestral lands. As a result many Nicaraguan families are reported to have moved across the Honduran border.

\section{Preventative Policing}

The first voices critical of hard-line approaches in dealing with youth violence in Central America appeared in the late 1990s [65]. Research supported by universities and NGOs questioned the effectiveness of reactive models in policing dealing with this problem. Of the Central American police institutions, the Nicaraguan police were the first to address the difficulties of a predominantly repressive approach toward youth violence in 2001 [65]. Experience from the operation of a reactive approach, called Plan de Pandillas (Anti-gangs Plan) demonstrated that whilst successful in immediately reducing youth violence, it was less successful in delivering sustainability and legitimacy. It was argued that the Plan de Pandillas would not resolve the underlying causes of youth violence. On the contrary the reactive approach could turn the majority of the young and predominantly male adolescents into threats to security.

In contrast to this experience, an alternative project was implemented by the local government in the nearby town of Masaya combining measures of crime control with prevention activities. The successful outcome of this project spread to other cities such as Jinotepe and Leon and would also become one of the foundations for the updating of citizens councils and the introduction of the family assemblies mentioned above [65]. Also importantly with regards to the prevention of youth violence the project would result in the implementation of a broadly new strategy i.e. 1) an approach targeted to the criteria of different groups, 2) home visits to families with adolescents in risk groups, 3) organisation of civic work for youth at risk and 4) prevention activities at the community level. The Police also established a Directorate of Youth Affairs in 2003 at the national and departmental levels. It would be this Directorate that would also assume responsibility for the management of the Centres for Youth Training and Development-also mentioned above. This change towards an understanding that is Más Vale Prevenir Que Reprimir (Better to Prevent than Punish) is attributed with significant improvement in the indicators of youth violence in the country [66]. The number of youth gangs recorded in Managua decreased from over 118 in 2002 to approximately 34 in 2005 [67].

In an interview in February 2017 [68], (Now First) Commissioner General Xavier Davila Rueda made the claim that the operation of the jefes de sector were to a large degree responsible for preventing the spread of armed gangs and narcotics in Nicaraguan cities. They were key to the predictive and analytical capacity of the police. When attempts 
have been made by gangs and criminal cartels to establish themselves in communities the interaction between the sector heads and the family assemblies meant that they were immediately informed on, allowing for further targeted action by the national authorities to be taken. The jefes de sector represents in this way a low-tech mechanism with which to form human and low-cost lines of communication between the community and state authorities. Moreover they enable sensitivity by the police to the particular concerns of the local community such as robbery, drugs and delinquency. This is also significant given that the level of technical support to the Nicaraguan police-in rural areas in particular-is comparatively low (e.g. in my interviews with jefes de sector in Bluefields it became clear that police officers do not commonly carry radios, do not have regular access to information technologies, nor have designated motorised transport).

In discussing the role and importance of the jefes de sector in a recent interview [69] a former police officer offered the following comment:

Community is a central element of community policing, but something else is also important: control over territorial information. .. With jefes de sector there will be one for the urban area, one for the semi-rural, and another for the rural area. The jefe de sector should have an operative mandate. . a perimeter of $5 \mathrm{~km}^{2}$, and they should know that in this area there is an area of $2 \mathrm{~km}^{2}$ with 400 houses, that there are commercial areas between the houses, there is a cafe, ten businesses, the owners of these are so and so, their specializations such and such... They should know all of the details of their zone, and about all of the people who live there... A distinctive feature is also that they not only visit, they live there. The preventive work is to be seen in the neighbourhood, to celebrate a child's birthday with the piñata, close the street if necessary. . . They are invited to all these kinds of event. So, for the jefe de sector their operative mandate are all local details, whilst for the local community this is balanced with them being present in the community and walking the streets.

\subsection{From Preventative to Precarious?}

The close ties formed through the relationships between the jefes de sector and the family assemblies have enabled the Nicaraguan police to succeed with little (in a financial and material sense). However, the occurrence of violence in the Atlantic Autonomous regions might not only be explained by dynamics of colonization and party alliances, but by the fact that the police are simply not sufficiently present in these areas of tension. According to a recent report there were 11,700 active personnel, 30 percent of them women, in 2011 , giving the country a rate of 199 officers per 100,000 inhabitants, which is low relative to the region, and significantly below the world average of 300 [70]. The number of officers is up from 10,500 in 2010 . Some 1,200 new officers entered the force in 2011 , setting a record for the biggest expansion in a single year. According to news report from 2015 , the size of the police force is currently at the level of 13,000 personnel [71]. Given that the national population is over 3 million and that most of the police personnel are located in urban centers, there are large areas of the country where police coverage is very low-including the rural areas of the Atlantic autonomous regions. According to the local police commissioner in Bluefields there are only 265 police officers in the entire Southern Autonomous district (over $27,000 \mathrm{~km}^{2}$ ).

The placement of jefes de sector in rural communities assists the creation of a police presence, but it is also evident that many of these officers are incredibly isolated in terms of necessary back up when serious crime occurs. Left largely on their own within local communities it is possibleas some of our interview respondents suggested-that the jefes de sector are more susceptible to bribery and corruption, as well as the misuse of their position of power. Indeed, it is clearly possible that because of the low territorial coverage of the police in Nicaragua in many cases crime may go unregistered by the national authorities. In 2016 and the start of 2017 the national police presented a 15\% reduction in the reporting of crime as a sign of their success. A direct correlation was made by the police command between reductions in reports of crime with a reduction in crime. However, as highlighted above, reports on citizen security carried out by independent analysts highlight the decrease in confidence that the public have in the police. It is suggested that the public have stopped reporting crime because the police fail to properly investigate and follow up on crime [72].

Whereas the model for community based policing in Nicaragua has had significant success there are also signs that the national administration is encouraging a turn towards more heavy-handed tactics in an effort to make up for poor coverage. In rural areas the military have always had a role in the provision of security, and taken a particular role in combatting the transportation of narcotics along the Nicaraguan Atlantic coast. The presence of specially trained militarized police units have, however, also become increasingly evident in Managua and Bluefields. In the case of Managua this is officially a response to a number of violent crimes in the city [73]. The police have now put into place the "Plan for the Strengthening of Security in the City of Managua" which according to official information is led by the Directorate of Special Police Operations (DOEP). It also involves the expanded use of the black uniformed Dantos Brigade in patrols and responses to reported violent crime in public spaces. According to a recent blog post by Roberto Cajina this is a sign that "the Police have lost their capacity to prevent and to be proactive, that they have lost their capacity to anticipate actions and guarantee the security of the population" [72]. Law 872 of the National Police Law establishes that the DOEP is a specialized department of the Police that "corresponds with the intervention to restore public order in serious altercations, to participate in special operations against drug trafficking, terrorism, orga- 
nized crime and other serious crimes". This is first time that the DOEP has been tasked with the response to everyday crimes. According to Cajina this is "the unfolding of the police special forces in the application of a "heavy hand" policy in response to common crime" [72].

The clear participation of the Dantos Brigade and the DOEP in the recent scenes of violence and policecommunity confrontations appears to support this argument. A series of protest were sparked in April 2018 following the decision by the Nicaraguan government to introduce cuts to pensions that would increase workers contributions and reduce overall benefits [74]. Although the government would cancel the welfare reform in response to the initial unrest, protest has nonetheless spread largely because of the heavy handed police response and government administrations claims that protest was the result of political manipulation by opposition groups. On the Atlantic Coast anger also boiled over into violent protest due to the perceived failure of police and governmental response to wildfires in the Indio Maíz biosphere [75]. Media coverage highlighted the presence of the black uniforms of the Dantos Brigade at the center of the violence both in the initial protests and multiple confrontations that would take place in Managua, Masaya and Bluefields in following weeks and months [76]. There are no reports of the military having intervened in these confrontations [75]. International and national media coverage has also emphasized the apparent alliance between the unit and balaclava clad para-police groups otherwise in civilian clothing. Media articles suggest that these parapolice groups are civilian volunteers from the Sandinista FSLN party [77]. The Nicaraguan government denies this [78]. The government claims that these groups represent criminal and interventionist interests including the United States [77]. It is these groups that are together attributed with the killing of $\mathrm{c} 300$ civilians [79] and continuing threats made to community and opposition activists. This violence has in turn generated a wave of condemnation from the international community, including calls for the Nicaraguan government to call early elections and the US government's proposal of a trade embargo of the country [80-82].

For some of the leadership of the National Police the return to a more political, presidential and militarized form of policing is a return to its historic Sandinista identity. In contrast, Cajina suggests this is "self-deception" [83]. He suggests that the National Police increasingly serve the President, and not the citizens. Even if there was a return to a more revolutionary ethos within the leadership of the national police, our interview respondents were also clear that it would no longer provide sufficient guidance to the force as a whole. A number of respondents made it clear that young people who are recruited into the police, including to work as jefes de sector, now had "more of an experience of poverty, than the ethics of the revolution". This made it difficult for young recruits to relate to or "to learn from the sayings of their elders" (aprender desde los dichos de sus mayores). The formal requirements of the recruitment process to the National Police states that candidates must be a Nicaraguan citizen, be of honorable behavior and vocation, have a good reputation and prestige in the community where they reside, and not have any previous criminal record. It is, however, also recognized by the police that many of those attracted to join the police do so, not out of a desire to serve the community, but because of a shortage of other economic alternatives [84].

These dynamics appear to suggest that the claims to preventative policing are under increasing pressure and contradiction. Indeed, regional dynamics in the Americas in general indicate that these pressures are likely to grow significantly in the years to come. The entire system of the Nicaraguan police is challenged by increasing efforts by the drug cartels and regionally based youth gangs to establish bridgeheads within the country, and within the Atlantic Autonomous regions in particular. Although geographically distant from Nicaragua the recent shift in the direction of US foreign policy and increased controls over immigration are also likely to end both the pressure valve of youth migration and remittances. With the disappearance of these opportunities tensions in the country are growing-particularly under the apparent current climate of presidentialism-and an increasing number of young people are pushed to either join criminal activities or join the police force out of necessity rather than conviction.

\section{Conclusions}

With its low levels of homicide and violent crime Nicaragua stands in strong contrast with the countries of the Northern Triangle. As has been discussed above, it is evident that the Nicaraguan model for community based policing (COP) has contributed significantly to these conditions. The Nicaraguan model for COP differed from others in the region due to its rejection of reactive policing and development of a system that emphasizes communitarian, proactive and preventative goals. Through the use of these guiding values and institutional structures the Nicaraguan COP model has until very recently depended much more on "social capital" (networks of relationships between people among people who live in a particular society), than other Central American COP models where high levels of financing, numbers of personnel and electronic information technology play a greater role [85]. The Nicaraguan COP model still carries some of the revolutionary ideals of Sandinista history. These are put into practice through the formation of a series of specific institutional structures, key amongst which are the family assemblies (gabinetes de familia), the sector or neighborhood officers (jefes de sector) and youth centers (centros de formación y desarrollo juvenil). Through these structures the national police were able to not only generate a strong contact with the local community, but ensure the rapid exchange of information regarding crime and local development concerns. They also enabled the police to proactively identify particular threats at an earlier stage and efficiently intervene to prevent and remove these risks. This has been particularly effective in containing the spread of 
youth gangs and organized criminal cartels attempting to operate in urban centres on Nicaragua soil.

Whilst in this way we corroborate earlier claims regarding the success of the Nicaraguan COP model, we also recognize that this model is currently under erosion. Changing circumstances make claims that it represents an example of good practice in public security increasingly untenable. The extraordinary violence and public unrest of recent months demonstrate that trust between the police and community, and the government and community are no longer what they once were. Public opinion regarding citizen's security and the efficiency of the police appears to be changing. Homicide levels are down according to official police statistics, but other reports suggest that robbery and drug related crime is growing in the cities. Whilst less crime is reported, indicators also suggest that fewer people trust the police to follow up on reported crime. It is also clear that the Ortega government recent efforts to bolster presidential power by restraining political opposition in parliament, by quelling public protest in the streets and by placing a series of public institutions directly under its control has had an impact on public trust in the state and police. As a result of the institutional changes made by the government, the police now have a permanent first commissioner and many of its social programmes, such as with women, removed from their control. Whilst the government argues for this in terms of bureaucratic efficiency, the removal of these responsibilities from the police has also removed vital points of communication with the community. The key institutional mechanisms mentioned above continue to function, but increasing critique is made of the way in which the Ortega government's particular brand of ideology i.e. Sandinismo mixed with conservative Catholicism, has intervened in their operation. Whilst there has been a long process to bolster professionalism in the national police, the tendency to promote some officers on the basis of party loyalties has resulted in an overly top-heavy leadership structure that it is little interested in innovation or renewal. Party alliance appears to be proactively replacing democratic communitarianism as the defining characteristic of who receives attention from these instances.

Concurrent with a politically driven erosion of police professionalism, it is also evident that there are a series of challenges to the Nicaraguan COP model's claims to be proactive and preventative. Indeed, it appears that issue of political alliances is at least a feature of the growing inability of the national police to respond to the growing levels of violence and insecurity developing in the Atlantic Autonomous Regions. In this context the police not only appear partisan, but are also failing to actively prevent rising tensions and further conflict. Certainly there seems to be a persisting gap in cultural and political respect and understanding between authorities in Managua and customary defined authorities of the Autonomous Regions. As we have described above, whilst the jefes de sector have had considerable success in urban areas, the low numbers of police in general and their frequent isolation with little technical and logistical back-up in rural areas is also a cause for concern. Claims of the involvement of jefes de sector in corruption and the misuse of power need to be taken seriously, particularly if this also takes on a partisan character.

The move by the national police to rely on specially trained armed units can also be seen as a politically driven move away from preventative policing. Whilst argued on the basis of a necessary reactive response to a recent rise in violent crime, the appearance of these units on neighbourhood patrols and civil protests has added further to the perception of institutional crisis and a politically driven attack on the foundational democratic values and action goals of the police. This has never been more evident than now in the context of current violent confrontations between the Dantos Brigade, para-police and community and opposition organizations. Indeed, as the institutional structures stagnate because of political favouritism, there is an increasing gap between the revolutionary rhetoric of its upper command with the actions and lived reality of economic hardship and exclusion experienced by both those newly drawn into its ranks and the community amongst which it aims to win hearts and minds. Changing regional conditions do not make this situation any easier. At a time when democracy is constrained, socio-economic differences are worsening and police presence is low and increasingly lacking in trust, it is becoming easier for the gangs and criminal cartels to solidly establish themselves in Nicaragua. The Nicaraguan model of community policing has functioned well under previous moments of extreme stress, such as the Contras struggle, but the institutional conditions surrounding its anchorage in the state and community have changed significantly.

Taken together these conclusions suggest that in a search for a critical foundation for human security-one not only concerned with public order, but public well-beingNicaragua needs to end the drift away from the original principles established for its model of community based policing. This we suggest should include reconsideration of the sociological and democratic foundations of the models original principles i.e. policing not in service of an authoritarian government but of service to and integration within the community. The effort to place these principles in practice serve as an explanation of the country's success in limiting crime in the past despite extremely challenging socio-economic conditions. The current government's apparent departure from adherence to these principles is at least part of the negative tendencies and current failures in policing. The model's, albeit now more historic than current emphasis on community or "social capital" also provides Nicaraguans, and perhaps populations beyond its borders, with a reminder that there are significant alternatives. In other contexts, analysts make a similar point in stating that an increase in public order policing will not help. In response to a context of social public order gone wrong the police need to become complicit or partisan towards the citizens that they serve [86]. Indeed, as has been more obvious in the current national crisis, the history of COP 
in Nicaragua makes evident that there are alternatives to the dominant regional trends of policing $[87,88]$ e.g. that emphasize centralized leadership, militarization and an over

\section{References and Notes}

[1] Countering Militarized Public Security in Latin America: Lessons from Nicaragua. Sustainable Security; Available from: https://sustainablesecurity.org/2013/11/12/community-policingin-nicaragua/.

[2] McClatchy, Johnson T. Nicaraguans, safe at home, feel little reason to flee to the U.S.; Available from: http://www.mcclatchydc.com/news/ nation-world/world/article24771970.html.

[3] Stone H. Exporting Nicaragua's Security Model. Insight Crime; Available from: http://www.insightcrime.org/news-analysis/exportingnicaraguas-security-model.

[4] Johnson S, Kareff S, Asavapromtada S. Nicaragua: Lessons from a Country with a Low Crime Rate. Centre for Strategic and International Studies.; Available from: https://csisprod.s3.amazonaws.com/s3fs-public/legacy_files/files/publication/ 120710_Johnson_Nicaragua_HemFocus.pdf.

[5] Cajina R. Security in Nicaragua: Central America's Exception. Security Dialogue; Available from: http://archive.thedialogue.org/ PublicationFiles/IAD8990_Security_Nicaragua_Eng_web.pdf.

[6] Union E. Country Strategy Paper and Multiannual Indicative Programme 2014-2010; Available from: https/::ec.europa.eu:europeaid: sites:devco:files:mip-nicaragua-2014-2020_en.pdf.

[7] (SIDA) SIDC. Evaluation of the Exchange and Technical Assistance between the Swedish Police and the National Police in Nicaragua; Available from: https://www.sida.se/ contentassets/77d48f06d6e54694b8337f4aa093c0d2/evaluationof-the-exchange-and-technical-assistance-between-the-swedishpolice-and-the-national-police-in-nicaragua_3316.pdf.

[8] Post W. Nicaraguan forces violently retake symbolic city. 17.07.2018; Available from: https://www.washingtonpost. $\mathrm{com} /$ world/the_americas/families-bury-the-dead-after-bloodyweekend-in-nicaragua/2018/07/16/1f832eba-895b-11e8-9d59dccc2c0cabcf_story.html?noredirect=on\&utm_term=.9bf6eb2d54f9.

[9] Research was carried out in Nicaragua in 2015 and 2017. The research was carried out with financing from the EU Horizon 2020 ICT4COP project. The research included a series of field visits and semi-structured interviews with a range of police personnel, ex-police officials, public officials, academics, representatives of community and civil society organizations. Research was conducted in both the capital Managua and Bluefields on the Atlantic Coast. Every effort was made to secure responses from as wide a cross section of respondents as possible. Secondary academic and media sources have also been extensively used. Given the sensitivities of the Nicaraguan state to questions regarding internal security this research would not have been possible without formal acceptance of research activity by the National Police and the Nicaraguan Ministry of Foreign Affairs. This approval open doors to important respondents within state institutions, but admittedly also created some limits to our correspondence with members of the political opposition in the country.

[10] Due to the political sensivities surrounding Nicaraguan security policy and the possibility of reprisals, we have chosen to anonymize the names of many of the people interviewed for this project. Whilst the names of top officials or authors of media articles have been kept, the names of police officers, community members, and civil society representatives have been removed from the article.

[11] Corresponding to the 1994 UN Human Development Report's definition of human security in which "freedom from fear" is matched with "freedom from want".

[12] Frühling $\mathrm{H}$. The impact of international models of policing in Latin America: the case of community policing. Police practice and re- reliance on the use of expensive technologies (information, communication, monitoring, weaponry etc.) at the expense of trust and human security. search. 2007;8(2):125-144. doi:10.1080/15614260701377638.

[13] Brogden M. "Horses for courses" and "thin blue lines": community policing in transitional society. Police quarterly. 2005;8(1):64-98. doi:10.1177/1098611104267328.

[14] Frühling $H$. A realistic look at Latin American community policing programmes. Policing and society. 2012;22(1):76-88. doi:10.1080/10439463.2011.636816.

[15] Ungar M, Arias ED. Reassessing community-oriented policing in Latin America. Policing and Society. 2012;22(1):1-13. doi:10.1080/10439463.2011.597856.

[16] Jütersonke O, Muggah R, Rodgers D. Gangs, urban violence, and security interventions in Central America. Security dialogue. 2009;40(45):373-397. doi:10.1177/0967010609343298.

[17] The Economist "A Surprising Haven"; With a GDP per head of USD 1,100 , Nicaragua can afford only 18 policemen for every 10,000 people, the lowest ration in the region. Earning USD120 per month its officers are also the worst paid. Available from: https://www.economist.com/node/21543492.

[18] Nicaraguan National Police. Modelo Policial de Nicaragua; Available from: http://www.policia.gob.ni/cedoc/ModeloPolicialfc.pdf.

[19] Aminta Granera, Director General of the Nicaraguan National Police, Panama. Graduation of Police Cadets. December 2014. El 19 Daniel preside acto de Graduación de Cadetes y Tecnicos Policiales; Available from: https://www.el19digital.com/articulos/ver/titulo: 24431-daniel-preside-acto-de-graduacion-de-cadetes-y-tecnicospoliciales.

[20] The evidence regarding homicide rates are not based on our own data, but research carried out by multiple institutions in the region of Central America. The Nicaraguan Police produce their own official annual homicide statistics. In line with these institutions we are aware that it is difficult to definitely state what these levels are, and there might be significant problems of both over reporting and underreporting. This is in part due to institutional capacity, to corruption, political manipulation of statistics, poor policing, and due to the difficulties of state oversight in areas that are remote or largely controlled by illegal forces (e.g. inner city neighborhoods overrun by gangs, or rural areas where there is a strong presence of drug cartels).

[21] Nicaraguan National Police. Visión Policial. Revista de la Policia Nacional. February 2017; Available from: http://www.policia.gob.ni/wpcontent/uploads/2017/vp2017/VP-feb-2017.pdf.

[22] At the level of Central America the official statistics of police reveal that there were 17,344 homicides in $2016(9.9 \%$ less than 2015). El Salvador is currently the most violent country in the Western Hemisphere, registering approximately 6,650 homicides in 2015 for a staggering homicide rate of 103 per 100,000 residents. The 2014 murder rate in Honduras fell from 68 to 57 per 100,000 people. Guatemala's murder rate was relatively stable, at 30 per 100,000 in 2015 compared to 38 per 100,000 in 2014.

[23] Pyper N. What is really behind Central America's sky-high murder rates. SBS; Available from: http://www.sbs.com.au/news/dateline/ article/2017/02/22/whats-really-behind-central-americas-sky-highmurder-rates.

[24] Prevenir. Sistematización Experiencias de implementación de Policía Comunitaria en cuatro países de Centroamérica.

[25] Cuadra E. La seguridad democrática: una política basada en la Policía comunitaria. San José: Instituto Centroamericano de Gobernabilidad (ICG); 2014.

[26] Canija R. Reforma del sector seguridad ciudadana, transición política y construcción democrática. Ley 290 y Ley 228. Mirador de Seguridad; 2009.

[27] Frühling $\mathrm{H}$. A realistic look at Latin American community policing programmes. Policing and society. 2012;22(1):76-88. doi:10.1080/10439463.2011.636816. 
[28] Cuadra E. El papel de la policía en conflictos de orden político [Lisencee degree monography]. Universidad Centroamericana (UCA), Menada, Nicaragua; 1995.

[29] Interview carried out by Skarlleth Martinez in February 2018.

[30] Prevenir Sistematización Experiencias de implementación de Policía Comunitaria en cuatro países de Centroamérica. San Salvador: Deutsche Gesellschaft für. 2014.

[31] República de Nicaragua. Reforma a la Constitución Política de Nicaragua en 1995. Ley 199; Available from: http://enriquebolanos. org/context.php?item=reforma-constitucion-1995-ley199-item.

[32] Asamblea Nacional de Nicaragua 1996. Ley 228, Ley de la Policía Nacional.;. Available from: http://legislacion.asamblea.gob.ni/Normaweb. nsf/\%28\$All\%29/88992F7FAA40EFAC06257116005D3CFF? OpenDocument.

[33] Women make up almost $30 \%$ of the Nicaraguan police force. This is one of the highest ratios in the world.

[34] McNeish visited the Centro de Juventud in the outskirts of Managua in 2015, and the Centro de Juventud in Bluefields in 2017.

[35] Política Policial Preventiva de Nicaragua; 2012. Available from: http://www.policia.gob.ni/cedoc/sector/prevenc/seminario_ regional_nicaragua.pdf.

[36] Cuadra E. La seguridad democrática: una política basada en la Policía comunitaria. San José: Instituto Centroamericano de Gobernabilidad (ICG); 2014.

[37] IEEPP 2013 XI Informe de Gestión de la Seguridad Democrática; Available from: https://www.ieepp.org/media/ files/XII_Informe_Gestion_WEB.pdf.

[38] IEEPP 2016 VIII Encuesta de percepciones sobre seguridad ciudadana; Available from: https://www.ieepp.org/publicaciones/ seguridad-ciudadana/publicacion-2-509/.

[39] Please note that in referring to comments made in semi-structured interviews all names have been removed or made anonymous. This is to guarantee that there can be no danger of reprisal.

[40] Cajina RA. Nicaragua-La Policia se ha desnaturalizado: es un satélite del régimen; Available from: http://www.alterinfos.org/spip. php?article7878.

[41] Goett J, Desiree Morris C. NACLA Reporting on the Americas;. Available from: http://nacla.org/news/2016/09/16/nicaragua'sauthoritarian-turn-not-product-leftist-politics.

[42] Cajina R. Security in Nicaragua: Central America's Exception? InterAmerican Dialogue Working Paper; 2013.

[43] IEEPP 2013 ¿Somos un país seguro? Encuesta de percepciones de seguridad ciudadana; Available from: https://www.ieepp.org/ publicaciones/seguridad-ciudadana/publicacion-2-364/.

[44] IEPP has now been closed by Nicaraguan state due its criticism of the current government.

[45] Romero E. La Prensa. 27/02/17. Crímenes detapan inseguridad en el país; Available from: https://www.laprensa.com.ni/2017/02/27/ nacionales/2189924-crimenes-destapan-inseguridad-en-el-pais.

[46] La Prensa Nicaragua. 25/02/2017. Video: Crece rearme en civiles. La Prensa; Available from: https://www.youtube.com/watch?v= p7FGjVruKqw.

[47] Ramirez P. El 19. El Jefe de Sector, un eslabón importante el relación Policia-Comunidad; Available from: https://www.el19digital.com/articulos/ver/titulo:33002-el-jefe-desector-un-eslabon-importante-en-la-relacion-policia-comunidad.

[48] El Nuevo Diario. El Centro de Fromación y desarrrollo juvenil "Juentud" de la Policia Nacional; Available from: http://www.elnuevodiario.com.ni/opinion/109106-centro-formaciondesarrollo-juvenil-juventud-polic/.

[49] Moreno J. La Prensa. 24.04.2015. Los Gabinetes de la famila; Available from: http://www.laprensa.com.ni/2015/04/24/opinion/1820571los-gabinetes-de-la-familia-3.

[50] Aburto W. Confidencial. De los CPC a los Gabinetes de Familia; Available from: https://confidencial.com.ni/archivos/articulo/10408/de-loscpc-a-los-gabinetes-de-la-familia.

[51] Moreno J. La Prensa. 24.04.15. Los Gabinetes de la famila; Available from: http://www.laprensa.com.ni/2015/04/24/opinion/1820571-losgabinetes-de-la-familia-3.

[52] El 19. Gabinetes de Familia, la comunidad y la vida profundizarón protagonismo y productividad de la Persona; Available from: https://www.el19digital.com/articulos/ver/titulo:7414-organizangabinetes-comunitarios-en-nicaragua.

[53] La Jornada. Aminta Granera seguirá como jefa policial con fecha indefinida; Available from: http://www.lajornadanet.com/diario/archivo/ 2016/julio/7/2.php.

[54] Metro. Policia Nacional confirma acción contra protestas al cana biooceánico; Available from: http://diariometro.com.ni/nacionales/ 15185-policia-de-nicaragua-confirma-accion-contra-protestas-alcanal-interoceanico/.

[55] Duarte J, Villareal R, Chammoro E. La Prensa. Policia bloquea la marcha campesina anticanal; Available from: http://www.laprensa.com.ni/2017/04/22/nacionales/2218313policia-bloquea-la-marcha-campesina-anticanal.

[56] Galanova M. Al Jazeera. Inside Nicaragua's bloody conflict over indigenous land; Available from: http://www.aljazeera.com/ indepth/features/2017/02/nicaragua-bloody-conflict-indigenousland-170206114438236.html.

[57] Downs, Ray. Vice News. Dec 2015. Available from: https://news.vice.com/article/violent-land-invasions-on-nicaraguasatlantic-coast-just-like-the-spaniards.

[58] The Northern and Southern Atlantic Autonomous-Regions are populated by indigenous peoples and ethnic communities with multilingual characteristics i.e. Miskitus, Creoles, Mayangas, Ramas and Garifunas.

[59] One third (33.3\%) of the total population of the Atlantic Coast is established in urban communities and the other two thirds $(66.7 \%)$ in rural zones.

[60] Larson AM, Lewis-Mendoza J. Decentralisation and devolution in Nicaragua's North Atlantic autonomous region: Natural resources and indigenous peoples' rights. International Journal of the Commons. 2012;6(2):179-199. doi:10.18352/bmgn-lchr.315.

[61] Plumer B. The fiasco that is the Nicaraguan canal, explained; Available from: https://www.vox.com/2015/2/26/8114151/nicaragua-canal.

[62] The Awas Tingni vs Nicaragua case. See https://www.escrnet.org/caselaw/2006/case-mayagna-sumo-awas-tingnicommunity-v-nicaragua-eng

[63] Downs R. Vice News. Violent Land Invasions on Nicaragua's Atlantic Coast; Available from: https://news.vice.com/article/violent-landinvasions-on-nicaraguas-atlantic-coast-just-like-the-spaniards.

[64] Prensa Libre. Conflicto por tierras desplaza centenares en Nicaragua; Available from: http://www.prensalibre.com/internacional/conflictopor-tierras-desplaza-a-centenares-en-nicaragua.

[65] Community Policing and Youth Violence Prevention Approaches and Implementation in El Salvador, Guatemala, Honduras and Nicaragua. Global Delivery Initiative-GIZ; Available from: http://www.gizprevenir.com/documentos/community-policingand-prevention-approaches.pdf.

[66] Cordero P. 28-31 de Octubre de 2003 VIII Congreso Internacional del CLAD sobre la Reforma del Estado y de la Administración Pública; Available from: http://unpan1.un.org/intradoc/groups/public/ documents/clad/clad0047902.pdf.

[67] Rocha JL, Rodgers D. Gangs of Nicaragua; 2008. Revista Envío: Managua.

[68] Interview carried out by McNeish at the Headquarters of the National Police in Managua.

[69] Interview carried our by Skarlleth Martinez in February 2018.

[70] Interview carried our by Skarlleth Martinez in February 2018; Available from: http://issat.dcaf.ch/Learn/Resource-Library/CountryProfiles/Nicaragua-Country-Profile.

[71] La Prensa. Policia Nacional aumentará numero de agentes; Available from: http://www.laprensa.com.ni/2015/03/06/nacionales/1794173policia-nacional-aumentara-numero-de-agentes.

[72] Cajina R. La Policia de ha desnutrilizado. Envio Digital; Available from: http://www.envio.org.ni/articulo/5323.

[73] A violent armed confrontation in streets of a neighbourhood of Managua left three people dead (two officers and one criminal); an attack with rifles on the house of an ex-judge supposed to be linked to organized crime; the killing of a citizen by an unknown assailant in another neighbourhood of the city.

[74] National Public Radio. Nicaragua's President Withdraws Social Security Reforms that Sparked Violent Unrest; Available from: 
https://www.npr.org/sections/thetwo-way/2018/04/22/604762080/violentunrest-continues-in-nicaragua-over-social-securityreforms?t=1532595129163.

[75] Can Nicaragua's Military Prevent a Civil War. Journal of Foreign Policy; Available from: https://foreignpolicy.com/2018/07/03/cannicaraguas-military-prevent-a-civil-war/.

[76] Infobae. Nueva jornada de violence en Nicaragua: al menos 14 personas fueron asesinados por el régimen de Daniel Ortega; Available from: https://www.infobae.com/america/america-latina/2018/ 07/08/nueva-jornada-de-violencia-en-nicaragua-al-menos-cincopersonas-fueron-asesinadas-por-el-regimen-de-daniel-ortega/.

[77] Ortega niega financiación de paramilitares y atribuye al narcotráfico y organizaciones "incluso de EEUU". Univisión; Available from: https://www.univision.com/shows/noticiero-univision/ortega-niegafinanciacion-de-paramilitares-y-la-atribuye-al-narcotrafico-uorganizaciones-incluso-en-eeuu-video.

[78] Bret Baier Confronts Nicaraguan President on Alleged Murders of Citizens. Fox News Insider; Available from: http://insider.foxnews.com/2018/07/23/bret-baier-interviewsnicaraguan-president-daniel-ortega-special-report.

[79] 309 Nicaraguans killed in 75 days of Anti-government Protests. Newsweek; Available from: https://www.newsweek.com/309nicaraguans-killed-75-days-anti-government-protests-1007469.

[80] Pope calls for end to violence in Nicaragua after deadly protests. Reuters; Available from: https://www.reuters.com/article/usnicaragua-protests-pope/pope-calls-for-end-to-violence-innicaragua-after-deadly-protests-idUSKCN1IZOFP.

[81] Condemn Egregious Abuses in Nicaragua; Available from: https://www.hrw.org/news/2018/06/22/oas-condemn-egregiousabuses-nicaragua.

[82] News C. US condems "Ortega Regime" amid deadly protests in Nicaragua; Available from: https:/www.cbsnews.com/news/ussecretary-of-state-mike-pompeo-condemns-ortega-regime-amiddeadly-protests-in-nicaragua/.

[83] Cajina R. La Policía se ha desnutrilizado. Envío Digital; Available from: http://www.envio.org.ni/articulo/5323.

[84] National Report on Human Development 2011: The young people building Nicaragua; According to a UNDP report (2011) $40 \%$ of young Nicaraguans are unemployed or work in the informal sector, while 50 percent live in poverty. Current levels of youth poverty and unemployment have not changed significantly in recent years. Available from: http://www.undp.org/content/undp/en/home/ presscenter/articles/2011/12/07/-informe-nacional-de-desarrollohumano-2011-las-juventudes-construyendo-nicaragua-.html.

[85] This is evident in the case study articles produced by fellow ICT4COP collegues working elsewhere in Central and South America.

[86] Hornberger J. We need a complicit police! Political policing then and now. South African Crime Quarterly. 2014;48(1):17. Available from: https://doi.org/10.17159\%2F2413-3108\%2F2014\% 2Fv0i48a790. doi:10.17159/2413-3108/2014/v0i48a790.

[87] Clavel T. Militarization and Crime: Central America's Dangerous Gamble. Insight Crime; Available from: https: //www.insightcrime.org/news/analysis/militarization-and-crimecentral-americas-dangerous-gamble/.

[88] Rights $\mathrm{CH}$; Available from: http://www.conectas.org/en/news/ militarization-security-rise-latin-america. 